5. Spiller, D. Assessment Matters: Self-assessment and peer assessment. Teaching Development Unit. 2012. URL: https://kennslumidstod.hi.is/wpcontent/uploads/2016/03/assessment-matters-self-assessment-and-peerassessment.pdf (accessed 16.04.2021).

6. Teaching Academic Writing / Coffin C., Curry M. J., and others. London: Routledge, 2003. 175 p.

7. van Zundert, M., D. Sluijsmans, and J. van Merriënboer. Effective peer assessment process: research findings and future directions. Learning and Instruction, 2010. 20: 270-27.

DOI https://doi.org/10.30525/978-9934-26-073-5-2-68

\title{
THE DIFFICULTIES OF ONLINE TEACHING UNDER CONDITIONS OF DISTANCE LEARNING (BASED UPON THE EXPERIENCE OF TEACHING PROFESSION-ORIENTED ENGLISH)
}

\author{
Kyrykylytsia V. V. \\ Candidate of Pedagogical Sciences, Associate Professor, \\ Associate Professor at the Foreign Languages Department for Natural \\ Sciences and Mathematics \\ Lesya Ukrainka Volyn National University
}

Onyshchenko I. A.

Senior Lecturer at the Foreign Languages Department for Natural Sciences and Mathematics Lesya Ukrainka Volyn National University

Yatsyniak O. P. Assistant Lecturer at the Foreign Languages Department for Natural Sciences and Mathematics Lesya Ukrainka Volyn National University Lutsk, Ukraine

Online teaching and learning have become increasingly popular since the quarantine period connected with the coronavirus pandemic started throughout the world. A sudden outbreak of COVID-19 has destabilized the entire educational system worldwide, forcing the educators to shift from the classroom to online mode during the pandemic period, which requires a 
symbiosis of e-technologies and distance learning in the educational process [3, p. 104].

According to the Law of Ukraine on Education, distance learning is defined as an individualized process of obtaining education, which takes place mainly through the indirect interaction of the distant participants of the educational process in a specialized environment that functions on the basis of modern psycho-pedagogical and information and communication technologies [4]. Scientists claim that distance learning belongs to a system of work when the teacher and the student are physically separated from one another but are connected through the methods of advanced information technologies [2. p. 401].

Since the beginning of the quarantine period both educators and learners are being forced to deal with the new and unusual situation and find the efficient ways of how to get organized and do all their best under conditions of distance teaching and learning. On the one hand, teachers feel professionally less certain as they have to search for the new strategies and to learn how to navigate them with confidence. On the other hand, distance learning can also be hard for the students who experience plentiful distractions when learning at home or in the dormitory.

The challenge of online teaching made us, the teachers of ProfessionOriented English course, replan students' activity in order to keep them engaged and motivated throughout the whole period of distance learning. At the beginning we felt anxious at the thought of conducting online classes. First of all, we had to be taught how to do it. We started to learn about online teaching with other online instructors at different types of online courses. Due to collaboration among the colleagues we have learned so much about new activities and class management issues. As we had a lot to learn by ourselves, it took a great deal of time, but step by step our efforts were paid off.

As a result of countless attempts and decisions, we managed to structure our Profession-Oriented English online lessons and adapt our classroom materials for online use. Nevertherless, we have experienced some difficulties connected with maintaining students' motivation, accessing digital technologies, making all the students be engaged and participate actively, promoting open class interaction, getting fast feedback, fair grading and time-consuming assignments and activities.

We are of the opinion that the most difficult things about online teaching are motivating students and making each online lesson enjoyable. We have learned that the best way to motivate students is by making each online assignment a part of their grade and giving deadlines to make sure that students are working through the material at the same pace at a regular basis. 
Primarily, to maintain the classroom dynamic we communicated with our students via text, video and/or audio methods using such online tools as Viber, e-mail, Skype. Later, we realized that to keep up students' motivation it is not enough to set regularly clear goals so that students have something to focus on. It became obvious that we needed something more innovative. Among a variety of distance-education platforms we made a choice for the platform Zoom that helped us combine all of the methods and teaching tools mentioned above. But we fully agree with J. Best that «no tool will work when you've got a confused student on one end and a struggling teacher on the other» [1].

The more we teach online, the more platforms and programs we have been considering in search for the effective ways of creating a supporting online community. Slowly, we have started to use Office 365 Teacher Academy, including Microsoft Teams and Microsoft Forms, Hangouts, Google Meet, Prometheus, Live Worksheets etc. All of them provide the right environment for better learning outcomes and are absolutely necessary to achieve the learning goals. Although, especially at the beginning, we had some problems with using digital platforms correctly and adapting our teaching materials to online lessons, we have greatly succeeded in applying these resources relevantly.

Generally speaking, thanks to a variety of distance-education platforms students have been able to continue their education during the university closure period and maintain their social connection with the educational institution. However, we have experienced challenges in accessing technologies. As it occurred, not every home always has a reliable internet connectivity or readily available device for students to use. Besides, there are always some students who say they have other internet problems like mute microphone or webcam and we often can hear a lot of excuses like «My microphone does not work» or «My webcam is broken». Undoubtedly, such problems negatively affect students' ability to learn the course material.

As it might have been expected, one of the most difficult things about teaching online is getting students engaged completely and making everyone participate actively. In an online learning environment group work, class discussion and collaborative activity, which are widely used by us in the practice of teaching Profession-Oriented English, have been somewhat troublesome. We can assume that under conditions of distance learning pair and group work very often looks asynchronous and is, therefore, unreasonable. It is not easy to have a conversation with a person next to you even if his/her camera is on. In addition, we have also experienced the situation when some students are camera-shy and, for that reason, they don't turn it on. If the participants of the educational process don't see each other faces during online 
lessons, open class interaction is almost impossible, and emotional interactive relationship and relationship-building are difficult to establish.

Furthermore, in the process of study students should receive timely feedback about their progress in order to know their strengths and weaknesses. But fast feedback remains to be a problem as a teacher is not able to monitor the whole group simultaneously at an online lesson. Such activities as presenting dialogues, role-plays and even monologues, which are common in Profession-Oriented English study, take longer time. Teachers check students' assignments submitted in the written form or as a video not only on their schedules but also at various times during the academic term. Moreover, teachers' comments require a sensible explanation and it takes more time to write it out than to say it. It becomes obvious that students cannot receive feedback at their earliest convenience.

Fair grading at online lessons is difficult to do as there is always the risk of cheating with the cameras turned off. The same thing is with grading students' assignments electronically which, in addition, might take some time. So, the teachers are not able to grade them quickly, efficiently and fairly.

Finally, assignments and activities that are adapted from a classroom setting to an online environment are time-consuming for all the participants of the educational process. To make a start with online teaching, teachers had devoted a lot of time into learning the classroom management system. Additionally, a lot of efforts went into planning the course and creating the resources that did a job instead of a teacher. We have realized that it also takes more time for students to work through online assignments than to complete and discuss the same activities at one class period.

Since we started teaching online, a lot of things have changed for us, especially, the matter of our daily and weekly workload. We have to find time to learn how to use digital resources and practice using them, plan each lesson carefully and establish routines for our students so they could know what is expected of them. Now we feel fortunate in that we gained necessary skills to teach both in the classroom and online. And we strongly believe that online teaching experience has provided us with the perfect opportunity to innovate and try something new that we just don't get in the classroom. In this regard, innovative resources and technologies have become an integral part of our professional advancement.

Despite some difficulties faced in conducting online lessons, we can conclude that online teaching has developed teachers' digital literacy and, as a result, has become somewhat more effective than traditional one. Distance education has benefited students' way of learning a lot as they are no more strictly supervised, guided and scheduled. It has required students to manage 
their own learning, to improve competence in decision-making, to encourage autonomous work and to become more independent and responsible.

\title{
References:
}

1. Best J. The Essentials of Online Teacher Student Communication. URL: https://www.3plearning.com/blog/teachers-can-communicate-effectively-online-learners/ (Retrieved: 20.04.2020)

2. Bondar N. Usage of distance technologies in modern educational process (on the examples of foreign languages). Педaгогічна освіта: теорія $і$ практика. 2020. Вип. 29, С. 398-406. DOI: https://doi.org/10.32626/2309-9763.2020-29-398-406.

3. Kalay D., Fedorenko S., Guryeyeva L., Kolomiiets S. Forming Students' Terminological Competence in the Moodle-Based E-Learning Course. Advanced Education. 2020. Is. 16, P. 104-11. DOI: 10.20535/24108286.216980.

4. Про освіту: Закон України від 16 липня 2019 р. № 10-р/2019 / Верховна Рада України. Відомості Верховної Ради України (ВВР). 2017. № 38-39. Ст. 9. URL: https://zakon.rada.gov.ua/laws/show/2145-19\#Text

DOI https://doi.org/10.30525/978-9934-26-073-5-2-69

\section{THE PROBLEM OF PEDAGOGICAL BARRIER IN THE ORGANIZATION OF EDUCATION PROCESS OF LEARNING ENGLISH}

\author{
Kryva K. O. \\ the first year student (magister) \\ Berdyansk State Pedagogical University \\ Glazkova I. Ya. \\ Doctor of Pedagogical Sciences, Professor, \\ Dean of the Department of Philology and Social Communications \\ Berdyansk State Pedagogical University \\ Berdyansk, Zaporizhzhia region, Ukraine
}

New socio-economic conditions of modern society and the gradual integration of Ukraine into the European community proposes new requirements for graduates, as well as the growing role and importance learning of foreign languages by students. Among the key competencies of the graduates, 254 